\title{
PENGELOMPOKAN BERBAGAI MERK MI INSTAN BERDASARKAN KEMIRIPAN KANDUNGAN GIZI DENGAN MENGGUNAKAN ANALISIS BIPLOT
}

\author{
Agustinus Angelaus Ete ${ }^{1}$, Ni Luh Putu Suciptawati², Desak Putu Eka \\ NILAKUSMAWATI ${ }^{3}$ \\ 1,2,3 Jurusan Matematika FMIPA Universitas Udayana, Bukit Jimbaran-Bali \\ e-mail:12agustinusete@yahoo.com, ${ }^{2}$ putusuciptawati@yahoo.co.id, ${ }^{3}$ nilakusmawati_desak@yahoo.com
}

\begin{abstract}
At this time, almost everyone once to consume instant noodles. The high interest of public on the instant noodles should be balanced with enough knowledge about the noodles and its nutritional content, either on it's instant noodles which have similar nutrient content and nutrient content that become identifier of each this group of noodles. The method can be used to obtain information on several brands of instant noodles that have similar nutrient content and nutrient content type that become identifier of each group of instant noodles is biplot analysis. Biplot analysis can show mie and nutrient content types simultaneously in a two-dimension plot. So that from a plot shows noodles and nutritional content types simultaneously, so that obtain information about the instant noodle that have similar nutrient content and nutrient content types into identifier of each group of instant noodles. This study was used 33 brands of instant noodles as observed objects with the type of nutrient content were observed there were nine. This study aims to find out some instant noodles that have similar nutrient content and nutrient content type that become identifier of each group of instant noodles. From the biplot analysis, obtained six groups of instant noodles with different identifier variables.
\end{abstract}

Keywords: Biplot Analysis, Similarity, Type of Nutrition

\section{Pendahuluan}

Dewasa ini, hampir semua orang pernah mengkonsumsi mi instan. Sifatnya yang praktis, mudah dihidangkan, rasanya enak, dan harganya yang terjangkau membuat mi instan menjadi daya tarik yang luar biasa bagi semua kalangan, mulai dari anak-anak hingga orang dewasa. Tingginya minat masyarakat terhadap mi instan perlu diimbangi dengan pengetahuan yang cukup tentang mi dan kandungan gizinya, baik itu tentang mi instan-mi instan yang memiliki kemiripan kandungan gizi maupun jenis kandungan gizi yang menjadi penciri dari masing-masing kelompok mi instan. Mengkonsumsi mi instan secara rutin tanpa mengetahui kandungan gizi yang terkandung di dalam mi instan bisa berdampak buruk bagi kesehatan.
Untuk mengetahui kemiripan kandungan gizi antarmi, maka perlu dilakukan pengelompokan mi instan dengan menggunakan analisis biplot. Analisis biplot dapat memberikan gambaran mengenai kedekatan antarmi berdasarkan kemiripan kandungan gizinya dalam bentuk plot dua dimensi sehingga baik digunakan sebagai acuan untuk melakukan pengelompokan. Mi instan yang memiliki kemiripan kandungan gizi akan digambarkan sebagai dua titik dengan posisi yang berdekatan dan mendapatkan sumbangan keragaman yang relatif sama dari vektor jenis kandungan gizi yang dimaksud. Jadi dengan menggunakan analisis biplot, bisa diperoleh tambahan informasi yang lebih baik tentang mi instan dan kandungan gizinya, baik itu tentang beberapa mi instan yang memiliki kemiripan kandungan gizi

\footnotetext{
${ }^{1}$ Mahasiswa Jurusan Matematika FMIPA Universitas Udayana

${ }^{2}$ Staf Pengajar Jurusan Matematika FMIPA Universitas Udayana
} 
maupun jenis kandungan gizi yang menjadi penciri dari masing-masing kelompok mi instan.

\section{Ulasan Pustaka}

\subsection{Analisis Biplot}

Analisis biplot merupakan salah satu teknik peubah ganda yang menyajikan plot pengamatan $n$ dan peubah $p$ secara bersamaan dalam bidang dua dimensi (Jollife, I.T. 2002). Penyajian plot pengamatan $n$ dan peubah $p$ secara bersamaan dapat memberikan tambahan informasi yang lebih baik tentang hubungan antara peubah dan pengamatan.

Empat hal penting yang bisa didapatkan dari tampilan biplot adalah (Mattjik, A.A. dan Sumertajaya, I M., 2011):

1. Kedekatan antarobjek yang diamati.

Kedekatan antarobjek diinterpretasikan sebagai kemiripan sifat dua objek. Semakin dekat letak dua objek maka kemiripan sifat dua objek tersebut semakin tinggi.

2. Keragaman peubah.

Keragaman peubah bisa dilihat dari panjang vektor peubah. Peubah dengan nilai keragaman kecil akan digambarkan sebagai vektor pendek sedangkan peubah dengan nilai keragaman yang tinggi akan digambarkan sebagai vektor panjang.

3. Korelasi antarpeubah.

Dua peubah dikatakan memiliki korelasi positif apabila digambarkan sebagai dua buah vektor yang membentuk sudut lancip. Dua peubah dikatakan memiliki korelasi negatif apabila digambarkan sebagai dua buah vektor yang membentuk sudut tumpul. Sedangkan dua peubah dikatakan tidak memiliki korelasi apabila digambarkan sebagai dua buah vektor yang membentuk sudut siku-siku.

4. Nilai peubah pada suatu objek.

Objek yang terletak searah dengan arah dari vektor peubah, memiliki nilai di atas ratarata. Sebaliknya, objek yang terletak berlawanan dengan arah vektor peubah, memiliki nilai di bawah rata-rata. Nilai peubah pada suatu objek digunakan untuk melihat peubah penciri dari setiap objek.
Nilai peubah pada suatu objek dapat dilihat dengan melakukan proyeksi ortogonal dari objek ke vektor peubah.

\subsubsection{Penguraian Nilai Singular}

Analisis biplot merupakan gambaran dua dimensi dari suatu matriks data $X$ yang menampilkan titik untuk masing-masing vektor pengamatan $n$ (vektor baris matriks $X$ ) bersama dengan titik untuk masing-masing $p$ peubah (vektor kolom matriks $X$ ) (Rencher, Alvin C., 2001). Dengan demikian biplot dibangun dari suatu matriks data $X$, denganmasing-masing baris mewakili objek penelitian dan masingmasing kolom mewakili suatu peubah.

$$
{ }_{n} X_{p}=\left[\begin{array}{ccc}
x_{11} & \cdots & x_{1 p} \\
\vdots & \ddots & \vdots \\
x_{n 1} & \cdots & x_{n p}
\end{array}\right]
$$

matriks $X$ memuat peubah-peubah yang akan diteliti sebanyak $p$ dan objek penelitian sebanyak $n$.

Analisis biplot didasarkan pada penguraian nilai singular. Definisi dari penguraian nilai singular adalah suatu matriks ${ }_{n} X_{p}$ yang dapat diuraikan menjadi:

$$
{ }_{n} X_{p}={ }_{n} U_{r} \quad{ }_{r} L_{r}{ }_{r} A_{p}^{\prime}
$$

Keterangan:

1. $U$ dan $A$ adalah matriks dengan kolom ortonormal $\quad\left(U^{\prime} U=A^{\prime} A=I_{r}\right) \cdot{ }_{p} A_{r}=$ $\left[a_{1}, a_{2}, \ldots, a_{r}\right]$ merupakan vektor ciri dari $X^{\prime} X$ dan ${ }_{n} U_{r}=\left[\frac{X a_{1}}{\sqrt{\lambda_{1}}}, \frac{X a_{2}}{\sqrt{\lambda_{2}}}, \ldots, \frac{X a_{r}}{\sqrt{\lambda_{r}}}\right]$, dengan $\lambda_{1}, \lambda_{2}, \ldots, \lambda_{r}$ merupakan akar ciri tidak nol dari $X^{\prime} X$.

2. $L$ adalah matriks diagonal berukuran $r \times r$ dengan unsur-unsur diagonalnya $\sqrt{\lambda_{1}} \geq \sqrt{\lambda_{2}} \geq \cdots \geq \sqrt{\lambda_{r}}$. Unsur-unsur diagonal matriks $L$ ini disebut nilai singular matriks $X$.

$$
L=\left[\begin{array}{cccc}
\sqrt{\lambda_{1}} & 0 & \ldots & 0 \\
0 & \sqrt{\lambda_{2}} & \ldots & 0 \\
\vdots & \ldots & \ddots & \vdots \\
0 & 0 & \ldots & \sqrt{\lambda_{r}}
\end{array}\right]
$$

3. Kolom-kolom matriks $A$ adalah vektor ciri dari $X^{\prime} X$.

4. $r$ adalah pangkat matriks $X, \quad r \leq$ $\min (n, p)$. 
Kemudian didefinisikan $L^{\alpha}$ untuk $0 \leq$ $\alpha \leq 1$ merupakan matriks diagonal berukuran $r \times r \quad$ dengan unsur-unsur diagonalnya $\lambda_{1}{ }^{\alpha / 2}, \lambda_{2}{ }^{\alpha / 2}, \ldots, \lambda_{r}{ }^{\alpha / 2}$. Definisi $L^{\alpha}$ berlaku juga untuk $L^{1-\alpha}$, sehingga diperoleh unsur-unsur diagonalnya $\lambda_{1}{ }^{1-\alpha / 2}, \lambda_{2}{ }^{1-\alpha / 2}, \ldots, \lambda_{r}{ }^{1-\alpha / 2}$. Misalkan $\quad G=$ $U L^{\alpha} \quad$ dan $\quad H^{\prime}=L^{1-\alpha} A^{\prime}$ dengan $\quad 0 \leq \alpha \leq 1$. Persamaan (2) dapat ditulis menjadi (Jollife, I.T. 2002):

$$
X=U L^{\alpha} L^{1-\alpha} A^{\prime}=G H^{\prime}
$$

Matriks $G$ memuat skor komponen utama yang merupakan titik-titik koordinat dari $n$ objek dan matriks $H$ memuat vektor eigen yang merupakan titik-titik koordinat dari $p$ peubah. Gambaran biplot dari matriks data $X$ diperoleh dengan mengambil dua kolom pertama dari matriks $G$ dan dua kolom pertama dari matriks $H$.

\subsubsection{Parameter $\alpha$}

Ada dua nilai $\alpha$ yang digunakan untuk mendefinisikan $G=U L^{\alpha}$ dan $H^{\prime}=L^{1-\alpha} A^{\prime}$, yaitu $\alpha=0$ dan $\alpha=1$.Jika $\alpha=0$, maka diperoleh persamaan sebagai berikut:

1. $G=U$ dan $H^{\prime}=L A^{\prime}$.

2. $X^{\prime} X=H H^{\prime}=S(n-1)$.

Hasil kali $h_{j}{ }^{\prime} h_{k}$ sama dengan $(n-1)$ kali kovarian $s_{j k}$ antara peubah ke-j dan peubah ke- $k$, di mana $j=1,2, \ldots, p$.

3. $\left\|h_{j}\right\|=\sqrt{n-1} s_{j}$.

Panjang vektor $h_{j}{ }^{\prime} h_{j}$ memberikan gambaran keragaman peubah ke-j.

4. $\quad r_{j k}=\frac{s_{j k}}{\sqrt{s_{j j} s_{k k}}}=\frac{h_{j} h_{k}}{\left\|h_{j}\right\|\left\|h_{k}\right\|}=\cos \theta$.

Korelasi antara peubah ke-j dan peubah ke- $k$ sama dengan nilai cosinus sudut antara vektor $h_{j}$ dan $h_{k}$.

5. $\delta_{h i}{ }^{2}=(n-1) d_{h i}{ }^{2}$.

Jarak Mahalanobis antara 2 pengamatan $x_{h}$ dan $x_{i}$ sebanding dengan jarak Euclidean antara dua pengamatan $g_{h}$ dan $g_{i}$. Dengan $\delta_{h i}{ }^{2}=\left(x_{h}-x_{i}\right)^{\prime} S^{-1}\left(x_{h}-x_{i}\right)$ merupakan jarak Mahalanobis antara 2 pengamatan $x_{h}$ dan $x_{i}$. Sedangkan $d_{h i}{ }^{2}=\left(g_{h}-g_{i}\right)^{\prime}\left(g_{h}-\right.$ $g_{i}$ )merupakan jarak Euclidean antara dua pengamatan $g_{h}$ dan $g_{i}$.

Secara keseluruhan pemilihan $\alpha=0$, akan memberikan kesesuaian untuk data dan keragaman. Tampilan biplot akan lebih mampu menggambarkan keragaman peubah, hubungan antarpeubah sekaligus mendapatkan informasi mengenai pola objek. Jika $\alpha=0$ yang digunakan, maka hasil pemfaktoran disebut $G H$ atau CMP biplot (Column Metric Preserving) (Lipkovich, I. and Smith, E.P., 2002).

Jika $\alpha=1$, maka diperoleh persamaan sebagai berikut:

1. $G=U L$ dan $H^{\prime}=A^{\prime}$.

2. $\left(x_{h}-x_{i}\right)^{\prime}\left(x_{h}-x_{i}\right)=\left(g_{h}-g_{i}\right)^{\prime}\left(g_{h}-g_{i}\right)$. Jarak Euclidean antara vektor pengaruh baris $g_{h}$ dan $g_{i}$ sama dengan jarak Mahalanobis antara $x_{h}$ dan $x_{i}$.

3. $x_{i j}=\sum_{k=1}^{r} z_{i k} a_{j k}$.

Vektor pengaruh baris ke- $i \quad\left(g_{i}\right)$ sama dengan skor komponen utama ke- $k$ dari objek ke-i.Di mana $z_{i k}=u_{i k} \lambda_{k}{ }^{1 / 2}$ adalah skor komponen utama ke- $k$ dari objek ke- $i$ dan $a_{j k}$ adalah pembobot pada peubah ke-j pada komponen utama ke- $k$. Untuk $G=U L$, maka unsur ke- $k$ dari vektor pengaruh baris $g_{i}$ sama dengan $z_{i k}$ pada analisis komponen utama. Untuk $H=A$, maka vektor pengaruh kolom $h_{j}$ sama dengan $a_{j}$ pada analisis komponen utama.

Dengan menggunakan $\alpha=1$, tampilan biplot akan lebih memberikan gambaran jarak antara pasangan baris sehingga baik digunakan untuk melihat kedekatan objek-objek. Jika $\alpha=$ 1 yang digunakan, maka hasil pemfaktoran disebut JK atau RMP biplot (Row Metric Preserving) (Lipkovich, I. and Smith, E.P., 2002).

\subsubsection{Ukuran Kelayakan Biplot}

Ukuran kelayakan biplot dua dimensi dirumuskan sebagai berikut (Gabriel, K.R., 1971):

$$
\rho_{2}^{(2)}=\frac{\lambda_{1}+\lambda_{2}}{\sum_{k=1}^{r} \lambda_{k}}
$$

dengan $\rho_{2}^{(2)}$ adalah ukuran kelayakan biplot dua dimensi untuk nilai $\alpha$ bersesuaian, $\lambda_{1}$ adalah 
nilai eigen terbesar pertama, $\lambda_{2}$ adalah nilai eigen terbesar kedua, dan $\lambda_{k}$ adalah nilai eigen terbesar ke- $k$ dengan $k=1,2, \ldots, r$. Apabila $\rho_{2}^{(2)}$ mendekati nilai satu, maka biplot memberikan penyajian yang semakin baik mengenai informasi data yang sebenarnya.

\subsection{Mi Instan}

Mi instan dibuat dari adonan terigu atau tepung beras atau tepung lainnya sebagai bahan utama dengan atau tanpa penambahan bahan lainnya. Bahan-bahan yang digunakan untuk membuat mi instan dibagi menjadi dua, yaitu bahan utama dan bahan baku lain yang dapat ditambahkan. Bahan utama merupakan bahan dasar yang digunakan untuk membuat mi, seperti terigu, tepung beras, air, atau tepung lainnya. Bahan baku lain yang dapat ditambahkan merupakan bahan yang digunakan untuk membuat bumbu mi, seperti garam, gula, lemak, minyak, vitamin, mineral, bahan penyedap rasa, dan aroma yang diijinkan ${ }^{[1]}$.

Pada mi instan, terkandung berbagai macam zat gizi berupa protein, lemak berupa lemak jenuh, karbohidrat meliputi serat pangan dan gula, dan mineral berupa natrium. Selain keempat zat gizi di atas, pada kemasan mi instan juga dicantumkan informasi mengenai energi baik itu energi total maupun energi dari lemak.

\section{Metode Penelitian}

Jenis data yang digunakan dalam penelitian ini adalah data sekunder. Peneliti menggunakan 33 merk mi instan sebagai objek amatan dengan jenis kandungan gizi yang diamati sebanyak sembilan.Perangkat lunak (software) yang digunakan dalam penelitian ini adalah Macros for Excel.

Adapun sembilan jenis kandungan gizi yang digunakan sebagai peubah penelitian, yaitu:

1. ET : Energi Total (kkal)

2. EL : Energi dari Lemak (kkal)

3. LT : Lemak Total (\%AKG)

4. LJ : Lemak Jenuh (\%AKG)

5. $\mathrm{P} \quad$ : Protein $(\% \mathrm{AKG})$

6. KT : Karbohidrat Total (\%AKG)
7. SP : Serat Pangan (\%AKG)

8. $\mathrm{G}$ : Gula (mg)

9. $\mathrm{N}$ : Natrium (\%AKG)

Metode analisis data dalam penelitian ini adalah sebagai berikut:

1. Melakukan Standardisasi data.

2. Membuat biplot data yang telah distandardisasi. Pada tahap ini meliputi penguraian nilai singular dan pembuatan plot.

3. Interpretasi hasil

\section{Hasil dan Pembahasan}

\subsection{Data Penelitian}

Peneliti menggunakan 33 merk mi instan sebagai objek amatan dengan kandungan gizi yang diamati sebanyak sembilan.Informasi mengenai nilai kandungan gizi dari 33 merk mi instandapat dilihat pada Tabel 1.

Berdasarkan data kandungan gizi pada Tabel 1, terdapat lima macam merk mi instan yang digunakan dalam penelitian ini, yaitu sarimi, indomie, mie sedaap, supermi, dan mi ABC. Masing-masing merk mi instan memiliki rasa yang beraneka ragam. Misalnya sarimi, yang terdiri dari sarimi rasa ayam, sarimi mi goreng rasa ayam kecap, sarimi soto koya jeruk nipis, sarimi rasa kari spesial, dan sarimi rasa soto. Sekilas meskipun mi instan-mi instan tersebut dihasilkan dari produsen mi yang sama, tetapi nilai kandungan gizi yang terkandung di dalam masing-masing mi instan berbeda satu sama lain untuk beberapa jenis kandungan gizi. Perbedaan nilai kandungan gizi ini disebabkan karena penggunaan bahan dasar dan bahan tambahan yang tidak sama baik secara takaran maupun variasi bahan dari masing-masing merk mi instan.

Ada tiga satuan pengukuran yang digunakan untuk menyatakan nilai dari setiap jenis kandungangizi yang terkandung dalam mi instan, yaitu kkal, \%AKG, dan mg. Jenis kandungan gizi yang menggunakan satuan 
pengukuran kkal adalah energi total (ET) dan energi dari lemak (EL). Jenis kandungan gizi yang menggunakan satuan pengukuran \%AKG adalah lemak total (LT), lemak jenuh (LJ), protein $(\mathrm{P})$, karbohidrat total (KT), serat pangan $(\mathrm{SP})$, dan natrium (N). Sedangkan jenis kandungan gizi yang menggunakan satuan $\mathrm{mg}$ adalah gula $(\mathrm{G})$.

Dalam analisis biplot, perhitungan jarak Euclidean, covarians, dan juga korelasi sangat rentan terhadap perbedaan satuan pengukuran antarpeubah. Karena satuan pengukuran yang digunakan pada penelitian ini tidak sama, maka data yang digunakan perlu distandardisasi terlebih dahulu. Standardisasi peubah dilakukan dengan cara mengurangkannya terhadap rataan kolom dan membaginya dengan standar deviasi kolom.

Tabel 1. Data Kandungan Gizi dari 33 Merk Mi Instan (Sebelum Distandardisasi)

\begin{tabular}{|c|c|c|c|c|c|c|c|c|c|c|}
\hline \multirow[b]{2}{*}{ No } & \multirow[b]{2}{*}{ Merk Mi } & \multicolumn{9}{|c|}{ Jenis Kandungan Gizi } \\
\hline & & ET & EL & LT & LJ & $\mathbf{P}$ & $\mathrm{KT}$ & SP & G & $\mathrm{N}$ \\
\hline 1 & SRA & 310 & 110 & 19 & 32 & 11 & 15 & 9 & 4 & 71 \\
\hline 2 & SSKJN & 320 & 120 & 21 & 33 & 10 & 15 & 9 & 4 & 60 \\
\hline 3 & SMGRAK & 590 & 220 & 39 & 65 & 18 & 27 & 16 & 13 & 59 \\
\hline 4 & SRKS & 540 & 200 & 37 & 62 & 16 & 24 & 15 & 6 & 77 \\
\hline 5 & SRS & 520 & 200 & 36 & 62 & 16 & 24 & 14 & 6 & 77 \\
\hline 6 & IRAS & 310 & 110 & 19 & 30 & 12 & 15 & 9 & 4 & 63 \\
\hline 7 & IMGP & 360 & 140 & 24 & 44 & 13 & 16 & 8 & 4 & 33 \\
\hline 8 & IMGRAP & 590 & 240 & 43 & 96 & 23 & 25 & 10 & 14 & 61 \\
\hline 9 & IRKA & 320 & 100 & 19 & 28 & 13 & 16 & 6 & 4 & 58 \\
\hline 10 & IMGRS & 370 & 130 & 24 & 35 & 13 & 17 & 7 & 8 & 45 \\
\hline 11 & IMGKP & 400 & 140 & 25 & 48 & 14 & 19 & 15 & 9 & 43 \\
\hline 12 & IMGKB & 430 & 150 & 27 & 42 & 14 & 20 & 14 & 9 & 51 \\
\hline 13 & IMGRR & 420 & 170 & 30 & 49 & 16 & 18 & 16 & 9 & 51 \\
\hline 14 & IRAB & 320 & 120 & 22 & 36 & 12 & 14 & 6 & 3 & 64 \\
\hline 15 & IMGRCI & 410 & 180 & 32 & 53 & 13 & 17 & 14 & 8 & 41 \\
\hline 16 & IMGC & 420 & 150 & 26 & 60 & 16 & 20 & 10 & 5 & 46 \\
\hline 17 & IRSM & 310 & 120 & 21 & 33 & 12 & 14 & 10 & 3 & 60 \\
\hline 18 & IMKRAP & 410 & 160 & 29 & 45 & 18 & 17 & 12 & 7 & 65 \\
\hline 19 & IMKGS & 410 & 160 & 28 & 42 & 18 & 18 & 12 & 9 & 48 \\
\hline 20 & MSRAS & 320 & 120 & 21 & 35 & 13 & 14 & 8 & 3 & 41 \\
\hline 21 & MSMKRS & 360 & 140 & 25 & 45 & 14 & 15 & 9 & 3 & 45 \\
\hline 22 & MSMKRKA & 340 & 130 & 23 & 41 & 14 & 15 & 8 & 3 & 43 \\
\hline 23 & MSRKS & 360 & 140 & 26 & 50 & 14 & 15 & 8 & 3 & 48 \\
\hline 24 & MSMKRAB & 320 & 120 & 22 & 42 & 13 & 14 & 9 & 3 & 41 \\
\hline 25 & SPRAS & 340 & 130 & 23 & 38 & 12 & 16 & 9 & 5 & 63 \\
\hline 26 & SPRS & 340 & 130 & 23 & 34 & 12 & 16 & 11 & 5 & 69 \\
\hline 27 & SPMG & 410 & 150 & 27 & 56 & 13 & 19 & 11 & 7 & 38 \\
\hline 28 & SPRSA & 350 & 140 & 25 & 42 & 11 & 16 & 19 & 5 & 53 \\
\hline 29 & SPRAB & 320 & 110 & 20 & 34 & 12 & 15 & 11 & 3 & 63 \\
\hline 30 & MABCRSAP & 330 & 120 & 22 & 36 & 10 & 15 & 9 & 1 & 95 \\
\hline 31 & MABCRSTP & 330 & 120 & 22 & 38 & 10 & 16 & 9 & 1 & 90 \\
\hline 32 & MABCRAB & 310 & 110 & 19 & 32 & 12 & 15 & 9 & 1 & 83 \\
\hline 33 & MABCRGAP & 10 & 110 & 21 & 33 & 10 & 16 & 9 & 3 & 90 \\
\hline
\end{tabular}

\subsection{Analisis Biplot}

\subsubsection{Pengelompokan Mi Instan}

Untuk memperoleh plot dua dimensi dari masing-masing merk mi instan dan jenis kandungan gizi, maka langkah awal yang perlu dilakukan adalah mencari titik koordinat dari masing-masing merk mi dan jenis kandungan gizi. Koordinat dari masing-masing merk mi instan dapat diperoleh dari matriks $G$ sedangkan koordinat dari masing-masing jenis kandungan gizi dapat diperoleh dari matriks $H$.
Berdasarkan data kandungan gizi yang sudah distandardisasi, dengan menggunakan bantuan Macros for Excel, maka diperolehmatriks $G$ yang memuat skor komponen dari dua komponen utama pertama dari data sebagai berikut. 
Tabel 2. Skor Komponen 1 dan Komponen 2 Data yang Distandardisasi

\begin{tabular}{|c|c|c|c|}
\hline No & Merk Mi & $\begin{array}{c}\text { Skor } \\
\text { Komponen } 1 \\
\end{array}$ & $\begin{array}{c}\text { Skor } \\
\text { Komponen } 2 \\
\end{array}$ \\
\hline 1 & SRA & -0.15896 & 0.090301 \\
\hline 2 & SSKJN & -0.14235 & 0.007353 \\
\hline 3 & SMGRAK & 0.427535 & 0.102982 \\
\hline 4 & SRKS & 0.278853 & 0.313828 \\
\hline 5 & SRS & 0.26241 & 0.298518 \\
\hline 6 & IRAS & -0.1521 & 0.00388 \\
\hline 7 & IMGP & -0.04495 & -0.2636 \\
\hline 8 & IMGRAP & 0.519936 & -0.01635 \\
\hline 9 & IRKA & -0.15884 & -0.07069 \\
\hline 10 & IMGRS & -0.03707 & -0.19054 \\
\hline 11 & IMGKP & 0.082446 & -0.13442 \\
\hline 12 & IMGKB & 0.09857 & -0.04236 \\
\hline 13 & IMGRR & 0.149335 & -0.0613 \\
\hline 14 & IRAB & -0.14749 & -0.00267 \\
\hline 15 & IMGRCI & 0.122221 & -0.13335 \\
\hline 16 & IMGC & 0.090839 & -0.11409 \\
\hline 17 & IRSM & -0.13873 & -0.00878 \\
\hline 18 & IMKRAP & 0.095842 & 0.017998 \\
\hline 19 & IMKGS & 0.112945 & -0.15503 \\
\hline 20 & MSRAS & -0.1287 & -0.21534 \\
\hline 21 & MSMKRS & -0.04329 & -0.15094 \\
\hline 22 & MSMKRKA & -0.07887 & -0.18859 \\
\hline 23 & MSRKS & -0.03581 & -0.13074 \\
\hline 24 & MSMKRAB & -0.10628 & -0.20648 \\
\hline 25 & SPRAS & -0.07879 & 0.021135 \\
\hline 26 & SPRS & -0.07722 & 0.096355 \\
\hline 27 & SPMG & 0.074325 & -0.17618 \\
\hline 28 & SPRSA & -0.00457 & 0.034224 \\
\hline 29 & SPRAB & -0.13397 & 0.035512 \\
\hline 30 & MABCRSAP & -0.16088 & 0.373114 \\
\hline 31 & MABCRSTP & -0.1484 & 0.335649 \\
\hline 32 & MABCRAB & -0.17622 & 0.224355 \\
\hline 33 & MABCRGAP & -0.16176 & 0.306256 \\
\hline
\end{tabular}

Setiap pasangan skor dari komponen 1 dan komponen 2 merupakan koordinat titik dari setiap merk mi instan pada plot dua dimensi.

Hal yang sama juga dilakukan untuk memperoleh matriks $H$. Untuk matriks $H$, dengan menggunakan bantuan Macros for Excel diperolehmatriks Hyang memuat dua vektor eigen pertama yang merupakan titik-titik koordinat dari masing-masing jenis kandungan gizi. Dua Vektor eigen pertama dari data yang distandardisasi disajikan pada Tabel 3.
Tabel 3. Vektor Eigen 1 dan Vektor Eigen 2 dari Data yang Distandardisasi

\begin{tabular}{|l|l|l|}
\hline Jenis Kandungan Gizi & Vektor Eigen 1 & Vektor Eigen 2 \\
\hline ET & 0.98264846 & 0.107442468 \\
\hline EL & 0.980140195 & 0.052882124 \\
\hline LT & 0.975680706 & 0.086443833 \\
\hline L & 0.915279474 & -0.026805601 \\
\hline P & 0.863652378 & -0.209719768 \\
\hline KT & 0.926975894 & 0.218594094 \\
\hline SP & 0.601275551 & 0.173647016 \\
\hline G & 0.865762037 & -0.219658275 \\
\hline N & -0.159155514 & 0.96108148 \\
\hline
\end{tabular}

Selanjutnya bila ingin diketahui sejauh mana biplot mampu memberikan informasi mengenai kemiripan kandungan gizi antarmi dalam plot dua dimensi, maka perlu dicari nilai eigen dari data awal yang distandardisasi dengan menggunakan bantuan Macros for Excel. Tabel 4 menyajikan nilai eigen yang diperoleh dari data kandungan gizi yang sudah distandardisasi.

Tabel 4 Nilai Eigen dari Data Awal yang Distandardisasi

\begin{tabular}{|l|l|}
\hline \multicolumn{1}{|c|}{ Eigen Values } & \multicolumn{1}{c|}{ Cumulative \% of Eigenvalues } \\
\hline 6.457549 & 0.717505 \\
\hline 1.116378 & 0.841547 \\
\hline
\end{tabular}

Berdasarkan data pada Tabel 4, pasangan komponen utama 1 dan komponen utama 2 dapat menjelaskan keragaman data sebesar 84.15\%. Dengan total keragaman data yang dapat dijelaskan dari kedua komponen utama pertama sebesar $84.15 \%$, biplot dianggap sudah cukup memberikan informasi mengenai kemiripan kandungan gizi antarmi.

Untuk mengetahui mi instan-mi instan yang memiliki kemiripan kandungan gizi, maka perlu dilihat posisi antarmi pada plot dan juga posisi dari masing-masing mi terhadap setiap vektor jenis kandungan gizi. Mi instan yang memiliki kemiripan kandungan gizi akan digambarkan sebagai dua titik dengan posisi yang berdekatan dan mendapatkan sumbangan keragaman yang relatif sama dari vektor jenis kandungan gizi yang dimaksud.Berikut ini adalah penggambaran biplot yang menampilkan 
titik untuk setiap merk mi instan dan vektor jenis kandungan gizi.

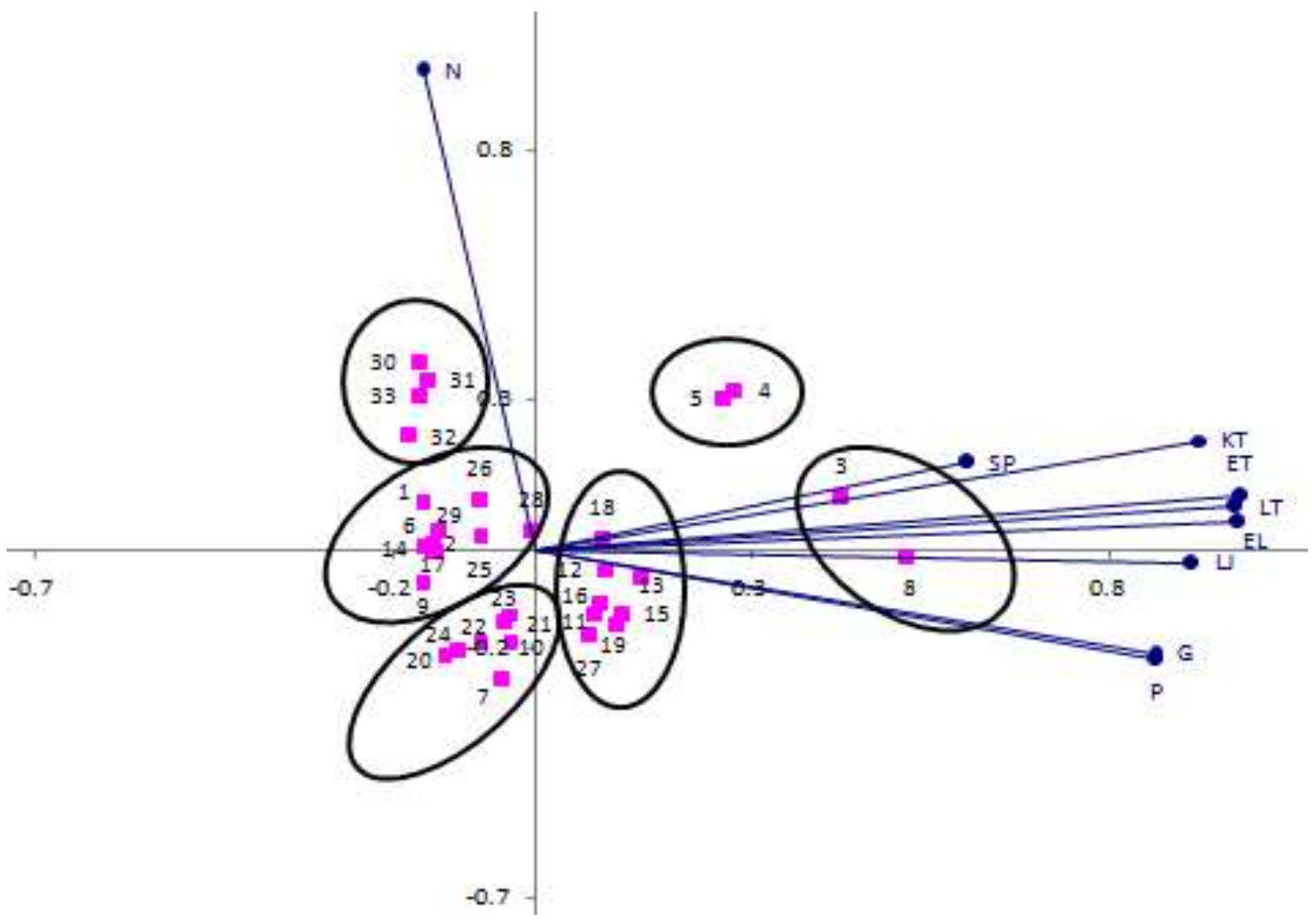

Gambar 1. Hasil Pemetaan Biplot untuk Mi dan Jenis Kandungan Gizi

Berdasarkan posisi dari 33 merk mi instan yang ditunjukan pada Gambar 1, maka dapat dibentuk enam kelompok mi instan. Keenam kelompok mi instan tersebut antara lain sebagai berikut:

1. Kelompok pertama, yaitu sarimi mi goreng rasa ayam kecap (3) dan indomie mi goreng rasa ayam panggang (8).

2. Kelompok kedua, yaitu sarimi rasa kari spesial (4) dan sarimi rasa soto (5).

3. Kelompok ketiga, yaitu mi $\mathrm{ABC}$ rasa semur ayam pedas (30), mi $\mathrm{ABC}$ rasa sup tomat pedas (31), mi $\mathrm{ABC}$ rasa ayam bawang (32), dan mi $A B C$ rasa gulai ayam pedas (33).

4. Kelompok keempat, yaitu indomie mi goreng kriuuk pedas (11), indomie mi goreng kriuuk bawang (12), indomie mi goreng rasa rendang (13), indomie mi goreng rasa cabe ijo (15), indomie mi goreng cakalang (16), indomie mi keriting rasa ayam panggang (18), indomie mi keriting goreng spesial (19), dan supermi mi goreng (27).

5. Kelompok kelima, yaitu sarimi rasa ayam (1), sarimi soto koya jeruk nipis (2), indomie rasa ayam spesial (6), indomie rasa kari ayam (9), indomie rasa ayam bawang (14), indomie rasa soto mie (17), supermi rasa ayam spesial (25), supermi rasa soto (26), supermi rasa semur ayam (28), dan supermi rasa ayam bawang (29).

6. Kelompok keenam, yaitu indomie $\mathrm{mi}$ goreng pedas (7), indomie mie goreng rasa sate (10), mie sedaap rasa ayam spesial (20), mie sedaap mie kuah rasa soto (21), mie sedaap mie kuah rasa kari ayam (22), mie sedaap rasa kari spesial (23), mie sedaap mie kuah rasa ayam bawang (24).

Setelah terbentuknya kelompok-kelompok mi instan, maka akan dilihat vektor jenis kandungan gizi mana yang memberikan 
sumbangan keragaman yang relatif besar terhadap masing-masing kelompok mi instan yang selanjutnya disebut sebagai peubah penciri dari masing-masing kelompok mi tersebut. Untuk itu akan dilakukan plot ulang hasil pengelompokan mi tadi, di mana data yang digunakan merupakan data nilai rata-rata dari setiap jenis kandungan gizi yang dimiliki masing-masing kelompok mi instan. Tabel 5memberikan informasi mengenai nilai rata-rata dari setiap jenis kandungan giziyang dimiliki masing-masing kelompok mi instan. Perhitungan nilai rata-rata menggunakan data kandungan gizi pada Tabel 1.

Tabel 5 Nilai Rata-Rata Setiap Jenis Kandungan Gizi dari Masing-Masing Kelompok Mi (Sebelum Distandardisasi)

\begin{tabular}{|l|l|l|l|l|l|l|l|l|l|}
\hline Kelompok Mi & \multicolumn{1}{|c|}{$\mathrm{ET}$} & \multicolumn{1}{|c|}{$\mathrm{EL}$} & $\mathrm{LT}$ & $\mathrm{U}$ & $\mathrm{P}$ & $\mathrm{KT}$ & $\mathrm{SP}$ & $\mathrm{G}$ & $\mathrm{N}$ \\
\hline Kelompok 1 & 590 & 230 & 41 & 80.5 & 20.5 & 26 & 13 & 13.5 & 60 \\
\hline Kelompok 2 & 530 & 200 & 36.5 & 62 & 16 & 24 & 14.5 & 6 & 77 \\
\hline Kelompok3 & 320 & 115 & 21 & 34.75 & 10.5 & 15.5 & 9 & 1.5 & 89.5 \\
\hline Kelompok 4 & 413.75 & 157.5 & 28 & 49.38 & 15.25 & 18.5 & 13 & 7.88 & 47.9 \\
\hline Kelompok 5 & 324 & 119 & 21.2 & 34 & 11.7 & 15.2 & 9.9 & 4 & 62.4 \\
\hline Kelompok 6 & 347.14 & 131.43 & 23.57 & 41.71 & 13.43 & 15.14 & 8.14 & 3.86 & 42.3 \\
\hline
\end{tabular}

Karena satuan pengukuran dari beberapa jenis kandungan gizi pada Tabel 5 tidak sama, maka data yang digunakan perlu distandardisasi terlebih dahulu. Standardisasi peubah dilakukan dengan cara mengurangkannya terhadap rataan kolom dan membaginya dengan standar deviasi kolom.

Untuk memperoleh plot dua dimensi dari masing-masing kelompok mi dan jenis kandungan gizi, maka langkah awal yang perlu dilakukan adalah mencari titik koordinat dari masing-masing kelompok mi dan jenis kandungan gizi. Koordinat dari masing-masing kelompok mi instan dapat diperoleh dari matriks $G$, sedangkan koordinat dari masing-masing jenis kandungan gizi dapat diperoleh dari matriks $H$.

Berdasarkan data kelompok mi yang sudah distandardisasi, dengan menggunakan bantuan Macros for Excel, maka diperoleh matriks $G$ yang memuat skor komponen dari dua komponen utama pertama dari data sebagai berikut.

Tabel 6. Skor Komponen 1 dan Komponen 2

Data yang Distandardisasi

\begin{tabular}{|l|l|l|}
\hline Kelompok Mi & \multicolumn{1}{|c|}{ Skor Komponen 1 } & Skor Komponen 2 \\
\hline Kelompok 1 & 0.685567 & -0.13223 \\
\hline Kelompok 2 & 0.348697 & 0.504135 \\
\hline Kelompok 3 & -0.43914 & 0.562315 \\
\hline Kelompok 4 & 0.053534 & -0.32936 \\
\hline Kelompok 5 & -0.3584 & -0.0567 \\
\hline Kelompok 6 & -0.29026 & -0.54815 \\
\hline
\end{tabular}

Setiap pasangan skor dari komponen 1 dan komponen 2 merupakan koordinat titik dari setiap kelompok mi instan pada plot dua dimensi.

Hal yang sama juga dilakukan untuk memperoleh matriks $H$. Untuk matriks $H$, dengan menggunakan bantuan Macros for Excel diperoleh matriks $H$ yang memuat dua vektor eigen pertama yang merupakan titik-titik koordinat dari masing-masing jenis kandungan gizi. Dua Vektor eigen pertama dari data kelompok mi yang sudah distandardisasi disajikan pada Tabel 7.

Tabel 7. Vektor Eigen 1 dan Vektor Eigen 2 Data yang Distandardisasi

\begin{tabular}{|l|l|l|}
\hline \multicolumn{1}{|c|}{ Jenis Kandungan Gizi } & Vektor Eigen 1 & Vektor Eigen 2 \\
\hline ET & 0.992152287 & 0.094452681 \\
\hline EL & 0.995951675 & 0.042046503 \\
\hline LT & 0.992004175 & 0.076702121 \\
\hline L & 0.987933613 & -0.02236233 \\
\hline P & 0.970124555 & -0.22391935 \\
\hline KT & 0.978907471 & 0.197265237 \\
\hline SP & 0.832722781 & 0.233572743 \\
\hline G & 0.909426033 & -0.30343471 \\
\hline N & -0.085824967 & 0.978837819 \\
\hline
\end{tabular}

Setiap pasangan skor dari vektor eigen 1 dan vektor eigen 2 merupakan koordinat titik dari setiap jenis kandungan gizi pada plot dua dimensi.

Selanjutnya bila ingin diketahui sejauh mana biplot mampu memberikan informasi atas data dalam plot dua dimensi, maka perlu dicari nilai eigen dari data kelompok mi yang sudah distandardisasi dengan menggunakan bantuan Macros for Excel. Tabel 8 menyajikan nilai 
eigen dari data kelompok mi yang distandardisasi.

Tabel 8. Nilai Eigen dari Data Awal yang Distandardisasi

\begin{tabular}{|l|l|}
\hline \multicolumn{1}{|c|}{ Eigen Values } & Cumulative \% of Eigenvalues \\
\hline 7.363621 & 0.81818 \\
\hline 1.210878 & 0.952722 \\
\hline
\end{tabular}

Berdasarkan data pada Tabel 8 , pasangan komponen utama 1 dan komponen utama 2 dapat menjelaskan keragaman data sebesar 95.27\%. Dengan total keragaman data yang dapat dijelaskan dari kedua komponen utama pertama sebesar $95.27 \%$, maka biplot dianggap sudah cukup memberikan informasi mengenai jenis kandungan gizi yang menjadi penciri dari masing-masing kelompok mi.

Setelah diperoleh koordinat dari masingmasing kelompok mi instan dan jenis kandungan gizi, maka selanjutnya dilakukan plot ulang masing-masing kelompok mi instan dan jenis kandungan gizi. Gambar 2 menunjukkan hasil penggambaran biplot yang menampilkan titik untuk setiap kelompok mi dan vektor jenis kandungan gizi.

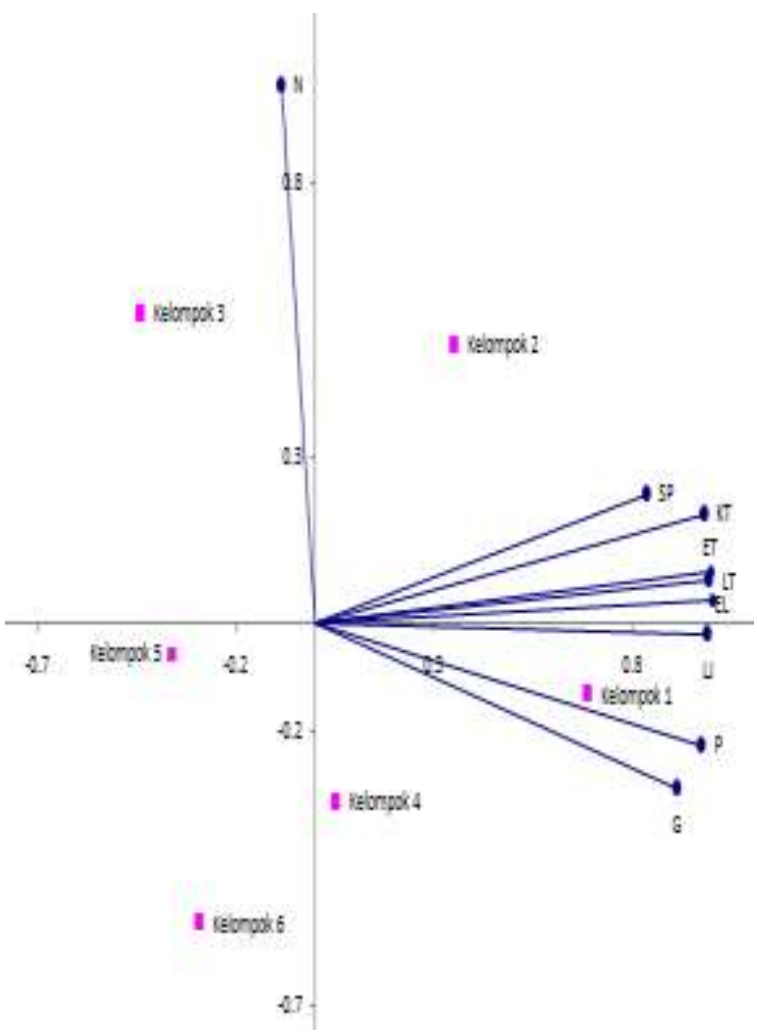

Gambar 2. Hasil Pemetaan Biplot untuk Kelompok Mi dan Vektor Jenis Kandungan Gizi
Untuk mengetahui jenis kandungan gizi yang menjadi penciri dari masing-masing kelompok mi instan maka perlu dilakukan proyeksi ortogonal dari masing-masing kelompok mi instan terhadap setiap vektor jenis kandungan gizi. Gambar 3 berikut menampilkan hasil proyeksi ortogonal dari setiap kelompok mi terhadap vektor jenis kandungan gizi yang menjadi pencirinya.

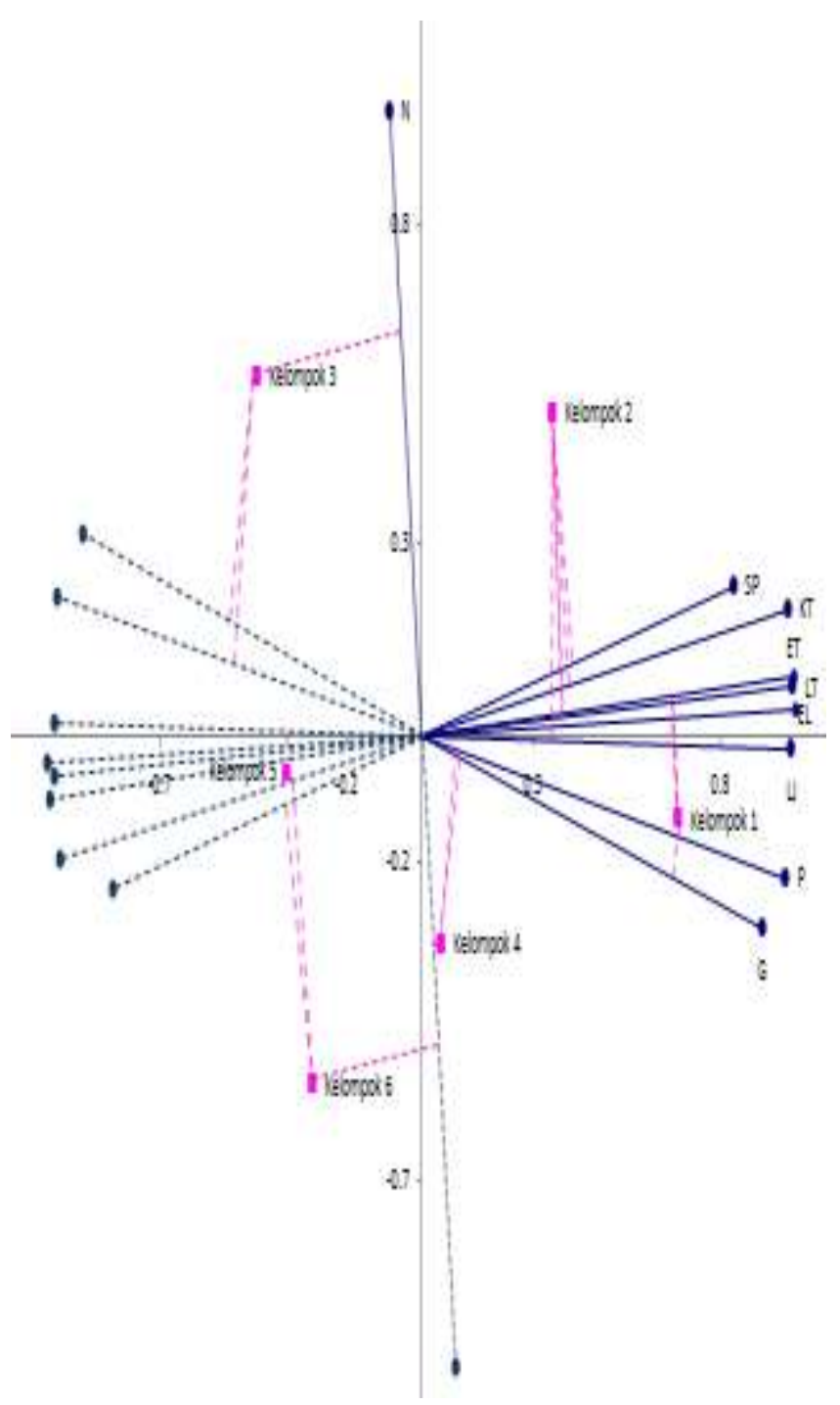

Gambar 3. Hasil Proyeksi Ortogonal dari Setiap Kelompok Mi Terhadap Vektor Jenis Kandungan Gizi yang Menjadi Penciri dari Setiap Kelompok Mi

Semakin jauh dari titik asal sebuah proyeksi dari objek jatuh pada vektor peubah, maka semakin besar nilai objek pada peubah tersebut. Sebaliknya, semakin dekat dengan titik 
asal sebuah proyeksi dari objek jatuh pada vektor peubah, maka semakin kecil nilai objek pada peubah tersebut.

Gambar 3 menunjukan bahwa mi instan kelompok 1 memiliki nilai kandungan gizi yang paling tinggi untuk jenis kandungan gizi protein $(P)$, gula $(G)$, lemak jenuh (LJ), dan energi lemak (EL). Dengan demikian jenis kandungan gizi yang menjadi penciri dari mi instan pada kelompok 1 adalah protein $(\mathrm{P})$, gula $(\mathrm{G})$, lemak jenuh (LJ), dan energi lemak (EL).

Hasil proyeksi otogonal yang ditunjukan pada Gambar 3, menunjukan jenis kandungan gizi yang menjadi penciri dari masing-masing kelompok mi, dan terangkum dalam Tabel 9.

Tabel 9 Jenis Kandungan Gizi yang Menjadi Penciri untuk Setiap Kelompok Mi

\begin{tabular}{|c|c|c|}
\hline Kelompok Mi & Merk Mi & Peubah Penciri \\
\hline Kelompok 1 & $\begin{array}{l}\text { Sarimi Mi Goreng Rasa Ayam Kecap (3) } \\
\text { Indomie Mi Goreng Rasa Ayam Panggang (8) }\end{array}$ & $\begin{array}{l}\text { Protein (P) } \\
\text { Gula (G) } \\
\text { Lemak Jenuh (L) } \\
\text { Energi Lemak (EL) }\end{array}$ \\
\hline Kelompok 2 & $\begin{array}{l}\text { Sarimi Rasa Kari Spesial (4) } \\
\text { Sarimi Rasa Soto (5) }\end{array}$ & $\begin{array}{l}\text { Serat Pangan (SP) } \\
\text { Karbohidrat Total (KT) } \\
\text { Energi Total (ET) } \\
\text { Lemak Total (LT) }\end{array}$ \\
\hline Kelompok 3 & $\begin{array}{l}\text { Mi ABC Rasa Semur Ayam Pedas (30) } \\
\text { Mi ABC rasa Sup Tomat Pedas (31) } \\
\text { Mi ABC Rasa Ayam Bawang (32) } \\
\text { Mi ABC Rasa Gulai Ayam Pedas (33) }\end{array}$ & $\begin{array}{l}\text { Natrium }(N) \\
\text { Gula }(G) \\
\text { Serat Pangan (SP) }\end{array}$ \\
\hline Kelompok 4 & $\begin{array}{l}\text { Indomie Mi Goreng Kriuuk Pedas (11) } \\
\text { Indomie Mi Goreng Kriuuk Bawang (12) } \\
\text { Indomie Mi Goreng Rasa Rendang (13) } \\
\text { Indomie Mi Goreng Rasa Cabe Ijo (15) } \\
\text { Indomie Mi Goreng Cakalang (16) } \\
\text { Indomie Mi Keriting Rasa Ayam Panggang (18) } \\
\text { Indomie Mi Keriting Goreng Spesial (19) } \\
\text { Supermi Mi Goreng (27) }\end{array}$ & $\begin{array}{l}\text { Natrium }(\mathrm{N}) \\
\text { Gula }(\mathrm{G}) \\
\text { Protein }(\mathrm{P})\end{array}$ \\
\hline Kelompok 5 & $\begin{array}{l}\text { Sarimi Rasa Ayam (1) } \\
\text { Sarimi Soto Koya Jeruk Nipis (2) } \\
\text { Indomie Rasa Ayam Spesial (6) } \\
\text { Indomie Rasa Kari Ayam (9) } \\
\text { Indomie Rasa Ayam Bawang (14) } \\
\text { Indomie Rasa Soto Mie (17) } \\
\text { Supermi Rasa Ayam Spesial (25) } \\
\text { Supermi Rasa Soto (26) } \\
\text { Supermi Rasa Semur Ayam (28) } \\
\text { Supermi Rasa Ayam Bawang (29) }\end{array}$ & $\begin{array}{l}\text { Energi Total (ET) } \\
\text { Lemak Total (LT) } \\
\text { Energi Lemak (EL) } \\
\text { Lemak Jenuh (L) }\end{array}$ \\
\hline Kelompok 6 & $\begin{array}{l}\text { Indomie Mi Goreng Pedas (7) } \\
\text { Indomie Mie Goreng Rasa Sate (10) } \\
\text { Mie Sedaap Rasa Ayam Spesial (20) } \\
\text { Mie Sedaap Mie Kuah Rasa Soto (21) } \\
\text { Mie Sedaap Mie Kuah Rasa Kari Ayam (22) } \\
\text { Mie Sedaap Rasa Kari Spesial (23) } \\
\text { Mie Sedaap Mie Kuah Rasa Ayam Bawang (24) }\end{array}$ & $\begin{array}{l}\text { Natrium (N) } \\
\text { Serat Pangan (SP) } \\
\text { Karbohidrat Total (KT) }\end{array}$ \\
\hline
\end{tabular}

Hasil yang ditampilkan pada Tabel 9 menunjukan bahwa peubah penciri dari masingmasing kelompok mi tidak sama. Dari Tabel 9, diketahui bahwa mi instan-mi instan pada kelompok 3 dihasilkan dari produsen mi yang sama yaitu mi ABC. Hal ini menunjukan bahwa meskipun mi ABC memiliki banyak aneka rasa tetapi nilai kandungan gizi yang terkandung di dalam setiap mi memiliki kemiripan untuk jenis kandungan gizi natrium $(\mathrm{N})$, gula $(\mathrm{G})$, dan protein $(\mathrm{P})$.

\section{Kesimpulan}

Dari hasil analisis biplot, diperoleh enam kelompok mi instan dengan peubah penciri yang yang berbeda. 


\section{Daftar Pustaka}

Badan Standardisasi Nasional. 2000. Mie Instan. Tim Penyiapan Konsep Revisi SNI 01-3551-1996.

Gabriel, K.R. 1971. The BiplotGraphic Display of Matrices with Application to Principal Componen Analysis. Jerusalem.

Jollife, I.T. 2002. Principal Component Analysis. Springer-verlag. New York.

Lipkovich, I. and Smith, E.P. 2002. Biplot and Singular Value Decomposition Macros for Excel. Blacksburg: Department of Statistics.

Mattjik, A.A. and Sumertajaya, I M. 2011. Sidik Peubah Ganda Dengan menggunakan $S A S$. Bogor: IPB PRESS.

Rencher, Alvin C. 2001. Method of Multivariate Analysis. United States of America: John Wiley \& Sons, Inc. 